\title{
THE TOXICITY OF LARGE DOSES OF PENTAQUINE (SN-13,276), A NEW ANTIMALARIAL DRUG ${ }^{1}$
}

\author{
BY BRANCH CRAIGE, JR.,2 LILLIAN EICHELBERGER, RALPH JONES, JR.,2 ALF \\ S. ALVING, THEODORE N. PULLMAN,2 AND C. MERRILL WHORTON 2
}

(From the Malarial Research Unit, Department of Medicine, University of Chicago)

(Received for publication January 4, 1947)

This paper reports observations on the toxicity of pentaquine ${ }^{\mathbf{3}}$ when administered in amounts higher than the recommended therapeutic dose (1). The purpose of the observations was to define the margin of safety of the drug in clinical use.

Pentaquine ( $\mathrm{SN}-13,276)$ offers considerable promise as a radical cure of vivax malaria $(1,2)$. It is closely related chemically to pamaquin (Figure 1). At dosage levels within the therapeutic range, the drug has seldom caused serious toxic reactions in white subjects. We have reported therapeutic results in 88 patients treated with 60 mgm. of base per day for 14 days (2). Most of them had few or no symptoms; only two subjects had severe symptoms, but not such as to make discontinuance of medication advisable. Symptoms, when they occurred, were similar to those produced by pamaquin: methemoglobinemia, abdomi-

1 This investigation was carried out under contract, recommended by the Committee on Medical Research, between the Office of Scientific Research and Development and the University of Chicago. This work was further aided by the participation of Army Medical Officers assigned to the project by the Surgeon General, U. S. Army.

Through a cooperative arrangement between Professor Clay G. Huff and Dr. Frederick Coulston, Department of Bacteriology and Parasitology, and the Malarial Research Unit, Department of Medicine, the former group bred Anopheles quadrimaculatus mosquitoes, supervised their infection and the inoculation of volunteers, and determined the intensity of infection in the salivary glands of the mosquitoes. The latter group assumed the responsibility for clinical care of patients studied by both groups.

The authors express their thanks to the Malaria Study Section of the National Institute of Health for editorial assistance and for arrangements in regard to the publication of this paper. They are also grateful to the Abbott Laboratories, E. I. du Pont de Nemours and Company, Inc., E. R. Squibb and Sons, Eli Lilly and Company, Sharp and Dohme, Inc., and Wyeth, Inc., for contributing toward the publication costs.

2 Captain, M.C., A.U.S.

${ }^{3}$ Pentaquine was synthesized by Dr. Nathan Drake at the University of Maryland. nal discomfort or pain, anorexia, nausea, and vomiting. No hemolytic crisis occurred, but none of the subjects were negroes, in whom the incidence of hemolytic episodes is high with pamaquin (1). Sixty mgm. of pentaquine base have a toxicity approximately equivalent to $30 \mathrm{mgm}$. of pamaquin base.

Pentaquine was administered in double or triple the maximal therapeutic dose of $60 \mathrm{mgm}$. per day in order to explore the prophylactic (3) and curative effect of the drug in vivax malaria and to define the upper dosage limits tolerated in man.

\section{PROCEDURE}

Details of the routine procedures used in these studies are reported elsewhere (4). The subjects were healthy, white, inmate volunteers ${ }^{4}$ in the Illinois State Penitentiary at Stateville. In prophylactic tests, the drug was administered to ten subjects at four-hour intervals for eight days at a daily dose of 120 or $180 \mathrm{mgm}$. of base. Inoculation with the bites of mosquitoes was performed<smiles>CCN(CC)CCCC(C)Nc1cc(OC)cc2c(N)ccnc12</smiles><smiles>COc1cc(NCCCNC(C)C)c2ncccc2c1</smiles>

Fig. 1. Structural Formulae of Pentaquine (SN13,276) and Pamaquin (Plasmochin)

\footnotetext{
4 These studies would not have been possible except for the enthusiastic cooperation of the inmate volunteers and administrative officials of Stateville Penitentiary.
} 
on the second day of drug administration. In highdosage therapeutic tests, $120 \mathrm{mgm}$. of pentaquine base was administered daily for 14 days to ten subjects who had acute clinical attacks of malaria at the start of treatment. In half of this latter group, 2.0 grams of quinine sulfate was administered daily concurrently with pentaquine. Certain individuals in both the prophylactic and high-dosage therapeutic trials failed to complete the scheduled course of treatment because of toxic reactions.

The volunteers were hospitalized during the entire course of drug administration and were interviewed for symptoms at least once daily. The following observations were made in all cases: rectal temperature, pulse and respiration every four hours; fluid intake and urinary output, blood pressure, methemoglobin and hemoglobin determinations, and urinalysis daily ; leucocyte count every two days; and differential count every four days. An electrocardiogram was made after treatment; and in most instances, non-protein nitrogen and serum bilirubin determinations, cephalin-cholesterol flocculation tests, and urinary urobilinogen estimations were performed at the end of the treatment period.

Hemoglobin and methemoglobin were estimated by the photocolorimetric method of Wendel (5). The concentration of drug in the plasma was determined by the modified (3) method of Brodie, Udenfriend and Taggart (6). Oxygen content and capacity and carbon dioxide content of the arterial and venous blood were determined by the gasometric method of Van Slyke and Neill (7) using arm blood.
The venous tone was measured in three patients by the use of a plethysmograph. The dilatation of the loosely gloved hand, when the venous pressure was increased from 10 to $50 \mathrm{~mm}$. $\mathrm{Hg}$ by applying pressure to the forearm through a sphygmomanometric cuff, was measured by the displacement of water. An interval of normal pressure was allowed after every reading, and the water was kept at $37^{\circ} \mathrm{C}$. in order to avoid errors due to edema and reactive hyperemia. The average of at least five determinations was used. The results were expressed in cubic centimeters per liter of hand volume in a manner similar to that used by Wilkins, Haynes and Weiss (8). Increased volume of the hand over that of normal controls was interpreted as implying decreased venous tone.

\section{RESULTS}

For convenience in analysis and presentation, the 20 subjects are divided into four groups of five volunteers as follows (Table I).

1. Therapeutic test at $120 \mathrm{mgm}$. base per day with quinine for 14 days. Drugs were administered concurrently in the treatment of clinical attacks.

2. Therapeutic test at $120 \mathrm{mgm}$. base per day without quinine for 14 days. The clinical attack was treated with pentaquine alone.

TABLE I

\begin{tabular}{|c|c|c|c|c|c|c|c|c|c|c|}
\hline \multirow[b]{2}{*}{$\begin{array}{l}\text { Case } \\
\text { no. }\end{array}$} & \multirow{2}{*}{$\begin{array}{l}\text { Type } \\
\text { of } \\
\text { trial }\end{array}$} & \multirow[b]{2}{*}{$\begin{array}{c}\text { Daily } \\
\text { dosage }\end{array}$} & \multirow{2}{*}{$\begin{array}{l}\text { Dura- } \\
\text { tion of } \\
\text { drug } \\
\text { adminis- } \\
\text { tration }\end{array}$} & \multirow{2}{*}{$\begin{array}{l}\text { Epigastric } \\
\text { or sub- } \\
\text { sternal } \\
\text { paint }\end{array}$} & \multirow{2}{*}{$\begin{array}{c}\text { Weakness, } \\
\text { prostra- } \\
\text { tiont }\end{array}$} & \multirow{2}{*}{$\begin{array}{c}\text { Syncope, } \\
\text { postural } \\
\text { hypo- } \\
\text { tensiont. }\end{array}$} & \multicolumn{2}{|c|}{ Hemoglobin } & \multirow{2}{*}{$\begin{array}{l}\text { Weight } \\
\text { loss } \\
\text { or } \\
\text { gain }\end{array}$} & \multirow[b]{2}{*}{ Antimalarial result } \\
\hline & & & & & & & $\begin{array}{l}\text { Converted } \\
\text { to } \\
\text { methemo- } \\
\text { globin }\end{array}$ & $\begin{array}{c}\text { Change } \\
\text { total } \\
\text { hemo- } \\
\text { globin }\end{array}$ & & \\
\hline $\begin{array}{l}1 \\
2 \\
3 \\
4 \\
5\end{array}$ & \multirow{2}{*}{ 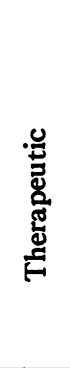 } & $\begin{array}{c}\text { mgm. } \\
120 \\
\text { with } \\
\text { quinine }\end{array}$ & $\begin{array}{l}\text { days } \\
14 \\
14 \\
14 \\
6 \frac{1}{6} * \\
14\end{array}$ & & $+t+$ & & $\begin{array}{c}\text { gm. per } \\
100 \text { cc. } \\
1.3 \\
1.0 \\
0.8 \\
0.7 \\
0.6\end{array}$ & $\begin{array}{c}\text { gm. per } \\
100 \text { cc. } \\
+0.4 \\
-0.2 \\
+0.3 \\
+0.2 \\
-0.2\end{array}$ & $\begin{array}{l}\text { kgm. } \\
-3 \\
-3 \\
-4 \\
0 \\
-2\end{array}$ & $\begin{array}{l}\text { No relapse in } 12 \text { months } \\
\text { No relapse in } 12 \text { months } \\
\text { No relapse in } 12 \text { months } \\
\text { No relapse in } 12 \text { months } \\
\text { No relapse in } 12 \text { months }\end{array}$ \\
\hline $\begin{array}{r}6 \\
7 \\
8 \\
9 \\
10\end{array}$ & & 120 & $\begin{array}{l}9 \frac{1}{3} \\
14 \\
14 \\
14 \\
14\end{array}$ & & $\begin{array}{c}+t+t \\
++++ \\
++t\end{array}$ & $\begin{array}{l}+t+t \\
+++t \\
++\end{array}$ & $\begin{array}{l}1.3 \\
2.0 \\
1.8 \\
1.5 \\
2.1\end{array}$ & $\begin{array}{c}0 \\
-3.4 \\
-2.1 \\
-3.9 \\
-3.6\end{array}$ & $\begin{array}{l}-5 \\
-11 \\
-3 \\
-10 \\
0\end{array}$ & $\begin{array}{l}\text { No relapse in } 12 \text { months } \\
\text { Relapsed in } 14 \text { days } \\
\text { Relapsed in } 26 \text { days } \\
\text { No relapse in } 12 \text { months } \\
\text { No relapse in } 12 \text { months }\end{array}$ \\
\hline $\begin{array}{l}11 \\
12 \\
13 \\
14 \\
15\end{array}$ & \multirow{2}{*}{ 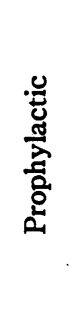 } & 120 & $\begin{array}{l}8 \\
8 \\
8 \\
8 \\
8\end{array}$ & & & & $\begin{array}{l}0.5 \\
1.3 \\
0.8 \\
0.9 \\
0.9\end{array}$ & $\begin{array}{l}-0.8 \\
-1.2 \\
-2.3 \\
-1.9 \\
-1.4\end{array}$ & $\begin{array}{l}+1 \\
+2 \\
+2 \\
+0\end{array}$ & $\begin{array}{l}\text { No attack in } 13 \text { months } \\
\text { No attack in } 13 \text { months } \\
\text { No attack in } 13 \text { months } \\
\text { Primary attack } 22 \text { days } \\
\text { No attack in } 13 \text { months }\end{array}$ \\
\hline $\begin{array}{l}16 \\
17 \\
18 \\
19 \\
20\end{array}$ & & 180 & $\begin{array}{l}5 \frac{1}{6} * \\
4 \frac{16}{8} \\
8 \\
4 \frac{1}{6} * \\
5 \frac{1}{6}\end{array}$ & & $\begin{array}{l}++ \\
++ \\
++\end{array}$ & & $\begin{array}{l}2.2 \\
1.2 \\
1.1 \\
2.7 \\
1.9\end{array}$ & $\begin{array}{l}-1.9 \\
-1.8 \\
-1.1 \\
-1.4 \\
-1.4\end{array}$ & $\begin{array}{r}0 \\
0 \\
+3 \\
+2 \\
+1\end{array}$ & $\begin{array}{l}\text { No attack in } 12 \text { months } \\
\text { No attack in } 12 \text { months } \\
\text { No attack in } 12 \text { months } \\
\text { No attack in } 12 \text { months } \\
\text { No attack in } 12 \text { months }\end{array}$ \\
\hline
\end{tabular}

* Drug fever.

$t+$ to ++++ represents severity of symptom. 
3. Prophylactic test at 120 mgm. base per day for eight days. These subjects did not have clinical malaria and did not receive quinine.

4. Prophylactic test at $180 \mathrm{mgm}$. base per day for eight days. These subjects were treated as in the previous prophylactic test but with a higher dosage of the drug.

The most common symptom was pain which was present in 19 of the 20 volunteers, and was severe in 13. Usually, after the first two or three days, the patients noted an epigastric discomfort, which in many became greatly aggravated and seemed to spread into the precordium or the retrosternal area. In a few patients the pain radiated to one or the other shoulder, to the back or to the neck. The ache or pain was constant with periodic exacerbation, and was accompanied in most cases by epigastric tenderness. In several individuals the epigastric tenderness was severe enough to limit the respiratory excursion, resulting in shallow, rapid respiration and "shortness of breath." A few patients described exacerbations of the pain after taking doses of the drug. In none was it apparently related to exercise, meals, defecation, or micturition. Efforts to relieve the pain with adrenalin or atropine were unsuccessful. The ordinary analgesics were withheld in order not to mask the signs of pentaquine toxicity.

In many instances the pain diminished or disappeared after the first three to eight days of treatment, but in others it persisted throughout treatment, subsiding gradually within the next two or three days. In one instance (120 $\mathrm{mgm}$. daily therapeutically with quinine) unexplained but very mild chest discomfort persists six months later.

Other transient symptoms occurring with less uniformity in the various groups, included anorexia, nausea, vomiting, headache, weakness and prostration.

Except for cyanosis, which was present whenever methemoglobinemia exceeded 6 or 7 per cent and frequently was detectable at lower values, few abnormalities were found on physical examination. Slight pallor was sometimes seen. The occurrence of drug fever on the fifth to seventh day of treatment necessitated discontinuation of the drug in three subjects. In a fourth, slight fever oc-
TABLE II

The toxicity of pentaquine in doses greater than the therapeutic dose

\begin{tabular}{|c|c|c|}
\hline $\begin{array}{c}\text { Pentaquine regime } \\
\text { (daily dose) }\end{array}$ & $\begin{array}{c}\text { Methemoglobin } \\
\text { formation } \\
\text { (average) }\end{array}$ & $\begin{array}{c}\text { Approximate } \\
\text { pamaquin } \\
\text { equivalent } \\
\text { (daily dose) }\end{array}$ \\
\hline $\begin{array}{l}\text { mgm. } \\
120 \text { prophylactic } \\
180 \text { prophylactic } \\
120 \text { with quinine } \\
\text { therapeutic } \\
120 \text { without quinine } \\
\text { therapeutic }\end{array}$ & $\begin{array}{c}\text { per cent of total } \\
\text { hemoglobin } \\
5.4 \\
13.1 \\
5.6 \\
11.3\end{array}$ & $\begin{array}{l}m g m . \\
45 \\
90^{*} \\
60 \\
90^{*}\end{array}$ \\
\hline
\end{tabular}

* Although the amounts of methemoglobin formed were almost the same, the second and fourth pentaquine regimes produced toxicity considerably in excess of that caused by $90 \mathrm{mgm}$. of pamaquin daily.

curred on the sixth day, treatment having been discontinued on the fifth day for other reasons.

A gradual loss in total hemoglobin commonly occurred, but no hemolytic crisis developed. All the subjects had methemoglobinemia. Using pamaquin as a standard of comparison, on the basis of the average amount of methemoglobin formed, the four groups may be compared with each other and with pamaquin (Table II). Very high degrees of methemoglobinemia were observed in the group at $180 \mathrm{mgm}$. alone and in the therapeutic group at 120 $\mathrm{mgm}$. without quinine. In the latter group, a loss of total hemoglobin combined with conversion of hemoglobin to methemoglobin produced a marked reduction in the blood pigment available for oxygen transport.

There was a diminution in the height of the $\mathrm{T}$-waves in the electrocardiograms in most of the subjects. The $\mathrm{T}$-wave amplitude was reduced in some or all leads. Inversion of $\mathrm{T}$-waves in Leads I and IV F occurred in one case. Occasionally also, an initially inverted $T_{3}$ became shallow or upright. The electrocardiographic changes were reversible.

In addition to the symptoms, signs and laboratory observations described above which were common to all the groups, serious physiological abnormalities were present in three of the subjects on $120 \mathrm{mgm}$. daily without quinine, given therapeutically. These patients displayed postural hypotension with syncope, arterial and venous oxygen unsaturation, and weight loss, which persisted for a long time after the end of treatment.

The three subjects were healthy, white males 
29 to 36 years old. They were inoculated, along with other volunteers, on March 2, 1946, with Plasmodium vivax (Chesson strain) by the bites of ten infected mosquitoes. Parasitemia and fever followed in 12 to 16 days, and the drug was begun within two days after the onset of fever. Pentaquine was given at a daily dose of $120 \mathrm{mgm}$. of the base, $20 \mathrm{mgm}$. being administered every four hours day and night for 14 days. Mean concentrations of the drug in plasma ranged between 48 and 103 gamma per liter. These concentrations did not differ significantly from those obtained in the volunteers less severely affected. The three subjects were afebrile, and the peripheral blood was free of parasites within four days of the end of treatment. The case records follow.

\section{Case 9}

During the first three days of treatment this patient complained of severe epigastric pain and tenderness, with periodic paroxysmal accentuation. During some of these extremely painful episodes an irregularity of the pulse was observed, which proved to be sinus arrhythmia by electrocardiograph. The pain disappeared spontaneously after three days, but profound weakness, nausea, and almost complete anorexia persisted throughout the twoweek trial. On the sixth day of treatment the patient experienced an attack of syncope and subsequently fainted repeatedly on assuming the upright posture. Cyanosis was noted early and persisted until a week or more after the end of treatment.

Calculated on the basis of five-day averages, a fall of 3.9 grams in total hemoglobin occurred during treatment. This fall was gradual, there being no acute hemolytic episode. The erythrocyte count decreased proportionately. Methemoglobinemia developed rapidly, the maximal levels being achieved on the third day and a fairly constant level being maintained thereafter. The average methemoglobinemia for the last five days of treatment was 1.8 grams per $100 \mathrm{cc}$., or 13.6 per cent of the total hemoglobin.

Urinalysis and total and differential leucocyte counts were normal during treatment, and after treatment no abnormalities were found in the blood non-protein nitrogen, blood sugar, serum bilirubin, sodium, potassium, and protein, arterial and venous carbon dioxide content, the venous pressure, arm-to-tongue circulation time, blood and plasma volume (Evans' blue method), and roentgenogram of the chest. The electrocardiogram showed a diminution in the height of the $T$ waves in Leads $I$, II, and IV F and a diminution of the previously inverted $T$ in Lead III. The Wintrobe red blood cell indices were within normal limits.

In addition to the low oxygen-carrying capacity due to methemoglobinemia and anemia, there was a striking diminution in the arterial and venous oxygen content
TABLE III

\begin{tabular}{|c|c|c|c|c|c|c|c|}
\hline \multirow[b]{2}{*}{ Case } & \multirow[b]{2}{*}{$\begin{array}{c}\text { Time } \\
\text { after } \\
\text { beginning } \\
\text { of } 2-\text { week } \\
\text { treatment }\end{array}$} & \multirow[b]{2}{*}{$\underset{\text { ity }}{\mathrm{O}_{2}}$} & \multicolumn{2}{|c|}{ Arterial } & \multirow[b]{2}{*}{$\begin{array}{c}\mathrm{O}_{2} \text { lost } \\
\text { by } \\
\text { blood } \\
\text { in per- } \\
\text { fusing } \\
\text { the } \\
\text { tissues }\end{array}$} & \multicolumn{2}{|c|}{ Venous } \\
\hline & & & $\begin{array}{c}\mathrm{O}_{2} \\
\text { con- } \\
\text { tent }\end{array}$ & $\begin{array}{l}\text { Oxy- } \\
\text { gena- } \\
\text { tion } \\
\text { of } \\
\text { hemo- } \\
\text { globin }\end{array}$ & & $\begin{array}{c}\mathrm{O}_{2} \\
\text { con- } \\
\text { tent }\end{array}$ & $\begin{array}{c}\text { Oxy- } \\
\text { gena- } \\
\text { tion } \\
\text { of } \\
\text { hemo- } \\
\text { globin }\end{array}$ \\
\hline $\begin{array}{r}\text { no. } \\
9\end{array}$ & $\begin{array}{c}\text { days } \\
13 \\
16 \\
28\end{array}$ & $\begin{array}{c}\text { vol. } \\
\text { per } \\
\text { cent } \\
16.45 \\
16.22 \\
18.16\end{array}$ & 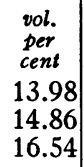 & $\begin{array}{c}\text { per } \\
\text { cent } \\
85.3 \\
91.9 \\
90.7\end{array}$ & $\begin{array}{c}\text { vol. } \\
\text { per } \\
\text { cent } \\
10.94 \\
6.20 \\
4.11\end{array}$ & $\begin{array}{c}\text { vol. } \\
\text { per } \\
\text { cent } \\
3.04 \\
8.66 \\
12.43\end{array}$ & $\begin{array}{l}\text { per } \\
\text { cent } \\
18.5 \\
53.4 \\
68.2\end{array}$ \\
\hline 7 & 38 & 19.40 & 17.40 & 89.6 & 9.06 & 8.34 & 43.0 \\
\hline 10 & $\begin{array}{l}13 \\
30\end{array}$ & $\begin{array}{l}14.75 \\
18.70\end{array}$ & $\begin{array}{l}12.68 \\
17.27\end{array}$ & $\begin{array}{l}85.7 \\
92.4\end{array}$ & $\begin{array}{l}8.17 \\
6.67\end{array}$ & $\begin{array}{r}4.51 \\
10.60\end{array}$ & $\begin{array}{l}30.2 \\
56.7\end{array}$ \\
\hline $\begin{array}{l}\text { Normal } \\
\text { blood }\end{array}$ & & 20.00 & 19.00 & 95.0 & 4.20 & 14.80 & 74.0 \\
\hline
\end{tabular}

and in the oxygen saturation of the remaining hemoglobin (Table III). Two weeks after the end of treatment, abnormal oxygen unsaturation was still present, although less pronounced than before.

Syncope not only on standing but even in the sitting position was a prominent symptom. The recumbent blood pressure at the start of treatment was $128 \mathrm{~mm}$. Hg systolic and 88 diastolic. At the end of treatment it was 98 systolic and 64 diastolic. Standing tests demonstrated that, when the patient assumed the upright position, the pulse rate increased (as is normal), but the blood pressure not only failed to show the normal physiologic rise, but precipitously fell, pressures of $\mathbf{4 5}$ systolic and 30 diastolic being recorded within one minute after standing. In seven tests, performed three weeks after the end of treatment, the patient fainted in $42,55,68,91$, 46,46 , and 43 seconds. Even when he "marked time" in the erect position the subject fainted in 55 seconds. After $0.4 \mathrm{cc}$. of 1:1000 epinephrine was injected subcutaneously, syncope occurred after 16 seconds of standing.

Two months after the end of treatment the tests were repeated, using a table tilted to 55 degrees. The use of the inclined table resulted in delaying the occurrence of syncope, permitting more time for observations. Even after this two-month interval, a fall in the systolic and diastolic blood pressure and an increase in the pulse rate occurred (Figure 2) followed by syncope. The reaction of this patient (Figure 2) may be compared with that of a normal individual (Figure 3). Four months after treatment the patient tolerated a short period of motionless standing and had a preliminary rise in blood pressure before the fall.

On the theory that the unusual degree of oxygen unsaturation might be due to stagnation in a dilated venous bed, the venous tone was measured. The distensibility of the hand veins was found to be greater than that of ten control subjects (Table IV). This observation made 


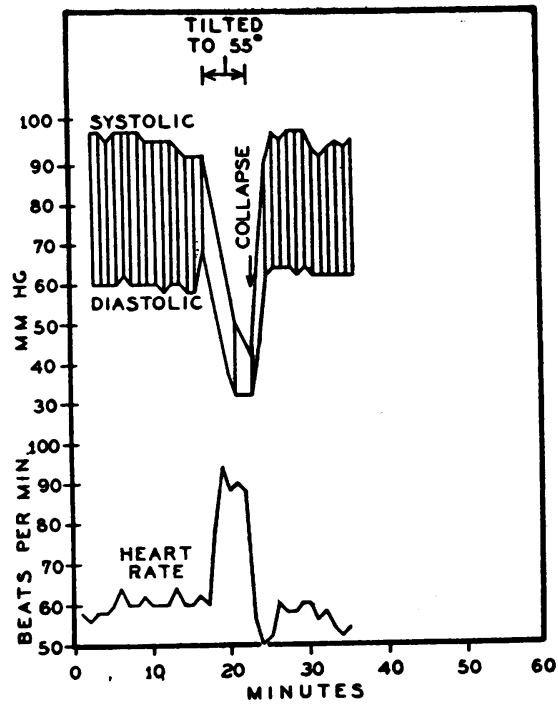

Fig. 2. Case 9. The Fall in Systolic and Diastolic Blood Pressure and the Rise in the Pulse Rate upon Tilting to $55^{\circ}$, Two Months after the End of Pentaquine Therapy

two months after the end of treatment, was confirmed at three months and again at four months.

Profound anorexia persisted for a long time, resulting in a weight loss of $10 \mathrm{kgm}$. in six weeks which was slowly and incompletely regained, in contrast to the rapid recovery of lesser weight loss in other subjects.

The patient was discharged from the hospital two and a half months after the therapeutic course. Although he returned to his routine work in the prison tailor shop,

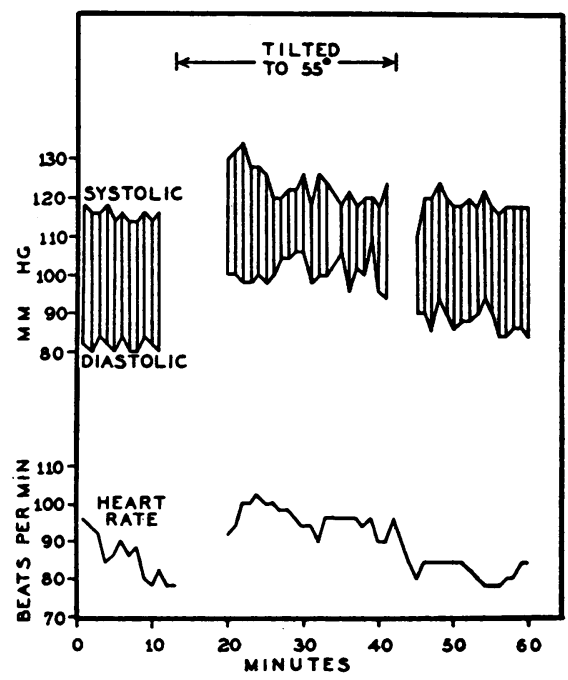

Fig. 3. Control Subject. The Rise in Systolic and Diastolic Pressures and Pulse Rate upon TiltING TO $55^{\circ}$
TABLE IV

Studies of hand volume

\begin{tabular}{|c|c|c|c|}
\hline Case & $\begin{array}{l}\text { Time after end } \\
\text { of treatment }\end{array}$ & \multicolumn{2}{|c|}{$\begin{array}{l}\text { Increase in hand volume when } \\
\text { venous pressure was increased } \\
\text { from } 10 \text { to } 50 \mathrm{~mm} \text {. Hg }\end{array}$} \\
\hline 9 & $\begin{array}{l}2 \text { months } \\
3 \text { months }\end{array}$ & \multicolumn{2}{|c|}{$\begin{array}{c}c c . \text { per liter } \\
24 \\
20\end{array}$} \\
\hline 7 & $\begin{array}{l}2 \text { months } \\
3 \text { months }\end{array}$ & \multicolumn{2}{|c|}{$\begin{array}{l}24 \\
22\end{array}$} \\
\hline \multirow[b]{2}{*}{10 controls } & & Range & Mean \\
\hline & & $8-20$ & 15 \\
\hline
\end{tabular}

he still has (four months after the test) giddiness in the morning, increased fatigability, and absence of erections and ejaculations.

\section{Case 7}

This volunteer suffered abdominal discomfort, similar to but milder than that of Case 9, lasting eight days; and he had more severe anorexia, nausea, vomiting, and weakness. He, too, began to faint on the sixth day of treatment and fainted repeatedly upon arising from bed for several weeks.

The laboratory observations were similar to those of the previous subject. He lost 3.4 grams of hemoglobin. Methemoglobinemia, as in Case 9, formed rapidly, averaging in the last five days, 2.0 grams per $100 \mathrm{cc}$. or 14.5

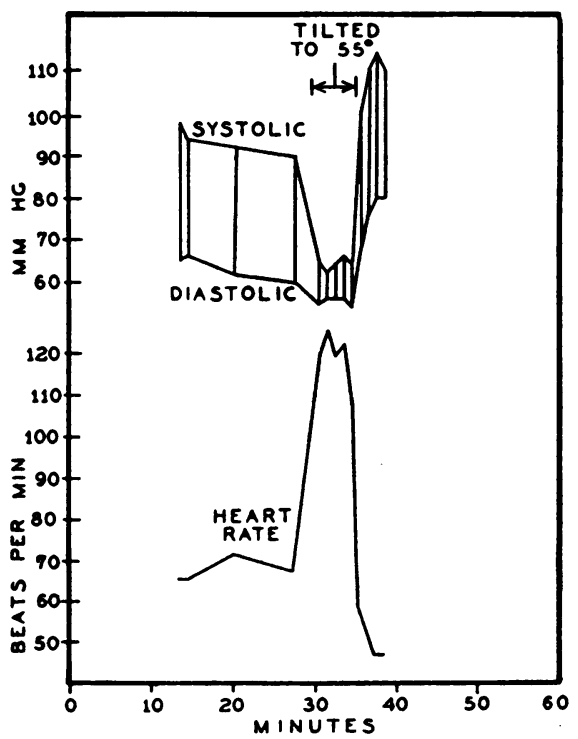

Fig. 4. Case 7. The Fall in Systolic and Diastolic Blood Pressure and the Rise in the Pulse Rate upon Tilting to $55^{\circ}$, Two Months after the End of Pentaquine Therapy 
per cent of the total hemoglobin. The same tests and observations were made as in Case 9. Only those yielding abnormal results will be discussed. The blood volume was not determined. Arterial and venous oxygen contents and per cent of saturation were abnormally low four weeks after the end of treatment (Table III).

The recumbent blood pressure, which was $120 \mathrm{~mm}$. $\mathrm{Hg}$ systolic and 84 diastolic at the start of treatment, fell to 94 systolic and to 66 diastolic at the end. Hypotension, followed by syncope when the patient stood upright, was still present four months after the end of treatment (Figure 4). As in Case 9, diminished venous tone was present and persisted for three months after the end of treatment (Table IV).

Severe anorexia resulted in a weight loss of $11 \mathrm{kgm}$., which was in part regained over the next four months.

The patient was discharged from the hospital seven weeks after the end of treatment. He returned to work in the prison tailor shop and at present still complains of increased fatigability and some dizziness, but has no impotence.

He suffered a malarial relapse 14 days after the end of treatment. It was treated with quinine sulfate, responded promptly, and no further relapse occurred.

\section{Case 10}

This volunteer had symptoms similar to, but less severe than, those of the other two subjects. The recumbent blood pressure, which was 112 systolic and 58 diastolic at the start of treatment, fell to 88 systolic and 54 diastolic a month later. He had postural hypotension and several episodes of syncope; but this symptom was much less troublesome than in the other two patients. Two months after the end of the treatment period prolonged standing did not produce syncope, and the venous tone was normal.

The $\mathrm{T}$-waves in the electrocardiogram diminished in amplitude. The total hemoglobin fell 3.6 grams per 100 cc.; and in addition 2.1 grams per $100 \mathrm{cc}$., or 16.7 per cent of the total hemoglobin, was converted to methemoglobin. Both during and after treatment, blood oxygen studies demonstrated arterial and venous unsaturation (Table III). No weight loss occurred. Impotence persisted for two months only.

\section{DISCUSSION}

The dosages of pentaquine administered in these studies are two or three times the dosage which has been found to be therapeutically necessary in a standardized infection (2) and are in excess of the amount that is safely tolerated in man.

There was an unexplained discrepancy between the severity of the toxicity encountered in the four groups of subjects. Possibly the discrepancies were due entirely to sampling, inasmuch as there were only five subjects in each group. The group on $180 \mathrm{mgm}$. of base suffered very severe symptoms, which may be a reflection of the size of the daily dose. That postural hypotension and syncope did not occur in the group on $180 \mathrm{mgm}$. may be due to the fact that treatment lasted only four to eight days. Of the three groups at 120 mgm., marked methemoglobinemia, significant hemoglobin loss, and postural hypotension and syncope were limited to those subjects receiving the drug without quinine for 14 days in a therapeutic trial. The longer duration of treatment was not the only factor causing this reaction, because in the therapeutic group receiving quinine, treatment also lasted two weeks.

Of the three groups at $120 \mathrm{mgm}$. a day, the one without clinical malaria and without quinine had the least toxicity; the group with malaria but without quinine had the most severe toxicity; and the group with malaria and quinine was intermediate in the severity of their symptoms. Whether malaria tends to aggravate the toxicity of pentaquine while the concomitant administration of quinine tends to lessen it in man, contrary to its effect in experimental animals $(1,8)$, cannot be determined without more extensive observations.

Methemoglobinemia, hemoglobin loss, abdominal distress or pain, chest pain, anorexia, nausea and vomiting are similar to the effects of pamaquin.

The occurrence of postural hypotension and syncope suggested an analogy with the effects of sodium nitrite as described by Wilkins, Haynes and Weiss (8). The effects of nitrites are transient, while the tendency to postural hypotension in two of these subjects persisted for months. Wilkins, Haynes and Weiss demonstrated that in subjects treated with nitrites the venous tone was diminished. When nitrite-treated volunteers were tilted to $75^{\circ}$, diastolic and systolic arterial pressures fell, the pulse rose, and syncope ensued. Epinephrine did not prevent syncope (9).

In the subjects studied for syncope after pentaquine we found, upon tilting, a similar fall in diastolic and systolic blood pressure not observed in control cases. As in controls, and as in nitritetreated subjects, the pulse rose. Since no observations of the venous tone in the affected subjects prior to pentaquine administration were available, comparison was made with venous tone values determined in ten control volunteers, all of whom 
had also experienced an attack of malaria within the preceding several months. The two patients with severe postural hypotention had lower venous tone than the range of the ten controls. The third patient, who had recovered from hypotension and syncope when the venous tone was measured, was within the normal range. In Case 9, as in nitrite-treated subjects, epinephrine was ineffective in preventing postural hypotension and syncope.

In toxic doses, pentaquine caused the symptoms commonly recognized with toxic doses of pamaquin. In addition, pentaquine may have exerted long-lasting effects on venous tone similar to that temporarily induced by the nitrites.

The disturbance in the blood pressure regulatory mechanism observed in these three patients bears a similarity to idiopathic postural hypotension wherein the blood pressure falls when the patient stands upright because of a failure in compensatory vaso-constriction. The blood in idiopathic hypotension distributes itself in the body under the influence of gravity, as though the arterial bed were unprovided with a vaso-constriction control (10). The etiology of idiopathic orthostatic hypotension is unknown; but inability to perspire and absence of sexual potence and ejaculations point to involvement of the central sympathetic system $(10,11)$.

Intoxication with pentaquine similarly caused loss of ejaculatory ability in two of the three hypotensive patients. Although studies of the toxicity of pentaquine in animals have not revealed a similar effect on blood pressure, it is of interest that Moe and Seevers (12) have obtained evidence of central impairment of sympathetic reflexes with high doses of pamaquin in dogs. The chemical and pharmacological similarity of pentaquine to pamaquin make these observations pertinent and suggests that the abnormalities produced in man by pentaquine may be due to injury of the sympathetic centers in the central nervous system.

The cases reported are unique in that they demonstrate orthostatic hypotension due to a known etiologic agent.

Many factors have to be considered as possible explanations for the apparent anoxic anoxia, obtained in Cases 9 and 10, thirteen days after the beginning of the treatment with the drug, such as : changes in the heart or lungs; damage to the red cells; the presence of methemoglobin or other abnormal blood pigments or a change in the oxygen combining properties of the hemoglobin.

Respiratory movements', though possibly limited by pain temporarily during treatment with pentaquine, were normal before the apparent arterial unsaturation disappeared; physical and roentgen examination of the chest failed to show evidence of obstruction, inflammatory reaction, collapse or emphysema, which might interfere with the passage of gases. The finding of a normal content of carbon dioxide in arterial and venous blood also failed to support the theory that local changes in the pulmonary tissues interfered with gaseous diffusion. Hematological observations did not disclose abnormalities in red cell size or shape which could account for poor oxygenation. Furthermore, in vitro, the red cells were capable of taking up oxygen.

There is a possibility that the oxygen saturation, in vivo, was normal but that, in vitro, the saturation was low because of an increase in the oxygen capacity. This state of affairs could occur in the presence of methemoglobin or other compounds containing iron in the ferric form (13). In these bloods there were appreciable amounts of methemoglobin ( 5 to 13 per cent of the total hemoglobin). According to Darling and Roughton (14) the reversion of methemoglobin occurs quite fast and thus produces an augmentation of the oxygen capacity.

An attempt was made to rule out this possibility by using the method of Sendroy $(15,16)$ for determining oxygen capacity. This method requires a shorter period for the complete oxygenation of hemoglobin and, thereby, might reduce the possibility of converting part of the methemoglobin to hemoglobin. The findings on one other patient were like the ones found by the classical method of Van Slyke used for the cases recorded in Table III.

The speed of the reconversion reaction may be too rapid for any general method now in use to exclude a reversion of the inactive pigment to the active gas combining form. Therefore, the explanation for the decrease in arterial oxygen saturation, obtained under the conditions of these studies, must await further observations.

The large arteriovenous oxygen difference (Table III) indicates that unusually large amounts 
of oxygen were lost by the blood in perfusing the tissues. There was no evidence of cardiac decompensation, either on physical examination or by measurement of the venous pressure and circulation time. The stagnant anoxia, therefore, can only be explained by changes in the peripheral circulatory bed, a concept supported by the finding of a decreased venous tone.

\section{SUMMARY}

Twenty volunteers at the Illinois State Penitentiary were treated with pentaquine ( $\mathrm{SN}$ $13,276)$, a new antimalarial drug related to pamaquin, in doses of 120 and $180 \mathrm{mgm}$. of the base per day. The purpose of these studies was to define the margin of safety of the drug in clinical use.

Most of the subjects experienced severe abdominal pain, nausea, anorexia, and methemoglobinemia similar to the symptoms produced by toxic doses of pamaquin.

Three subjects developed long-persistent postural hypotension and syncope, possibly due to central impairment of the sympathetic nervous system. Severe anoxia occurred during treatment and subsided over a period of weeks.

The doses used in these studies were at least double or triple the amount required for antimalarial chemotherapy.

\section{BIBLIOGRAPHY}

1. Loeb, R. F., Clark, W. M., Coatney, G. R., Coggeshall, L. T., Dieuaide, F. R., Dochez, A. R., Hakansson, E. G., Marshall, E. K., Jr., Marvel, C. S., McCoy, O. R., Sapero, J. J., Sebrell, W. H., Shannon, J. A., and Carden, G. A., Jr., Activity of a new antimalarial agent, pentaquine $\mathrm{SN}$ 13,276). Statement approved by the Board for Coordination of Malarial Studies. J. A. M. A., 1946, 132, 321.

2. Alving, A. S., Craige, B., Jr., Jones, R., Jr., Whorton, C. M., Pullman, T. N., and Eichelberger, L., Pentaquine (SN-13,276) a therapeutic agent effective in reducing the relapse rate in vivax malaria. J. Clin. Invest., 1948, 27, Suppl., 25.
3. Jones, R., Jr., Craige, B., Jr., Alving, A. S., Whorton, C. M., Pullman, T. N., and Eichelberger, L., A study of the prophylactic effectiveness of several 8-aminoquinolines in sporozoite-induced vivax malaria. J. Clin. Invest., 1948, 27, Suppl., 6.

4. Alving, A. S., Craige, B., Jr., Pullman, T. N., Whorton, C. M., Jones, R., Jr., and Eichelberger, L., Procedures used at Stateville Penitentiary for the testing of potential antimalarial agents. J. Clin. Invest., 1948, 27, Suppl., 2.

5. Wendel, W. B., Personal communication.

6. Brodie, B. B., Udenfriend, S., and Taggart, J. V., Analysis of basic organic compounds in biological tissues. IV. Coupling with diazonium salts. Fed. Proc., 1946, 5, 125.

7. Van Slyke, D. D., and Neill, J. M., The determination of gases in blood and other solutions by vacuum extraction and manometric measurement. I. J. Biol. Chem., 1924, 41, 623.

8. Wilkins, R. W., Haynes, F. W., and Weiss, S., The role of the venous system in circulatory collapse induced by sodium nitrite. J. Clin. Invest., 1937, $16,85$.

9. Wilkins, R. W., Weiss, S., and Haynes, F. W., The effect of epinephrine, in circulatory collapse induced by sodium nitrite. J. Clin. Invest., 1938, $17,41$.

10. East, T., and Brigden, W., Postural hypotension. Brit. Heart Jour., 1946, 8, 103.

11. Stead, E. A., and Ebert, R. V., Postural hypotension, a disease of the sympathetic nervous system. Arch. Int. Med., 1941, 67, 546.

12. Moe, G. K., and Seevers, M. H., Central impairment of sympathetic reflexes by plasmochin. Fed. Proc., 1946, 5, 193.

13. Roughton, F. J. W., Darling, R. C., and Root, W. S., Factors affecting the determination of oxygen capacity, content and pressure in human arterial blood. Am. J. Physiol., 1944, 142, 708.

14. Darling, R. C., and Roughton, F. J. W., The effect of methemoglobin on the equilibrium between oxygen and hemoglobin. Am. J. Physiol., 1944, 142, 708.

15. Sendroy, J., Jr., Manometric determination of hemoglobin by the oxygen capacity method. J. Biol. Chem., 1931, 91, 307.

16. Sendroy, J., Jr., Dillon, R. T., and Van Slyke, D. D., The solubility and physical state of uncombined oxygen in blood. J. Biol. Chem., 1934, 105, 597. 